\title{
INCIDENCE AND CHARACTERISTICS OF INSUFFICIENT BIRTH WEIGHT NEWBORNS FROM A COHORT OF NEONATES IN A PUBLIC REGIONAL HOSPITAL OF A METROPOLITAN AREA
}

\author{
Roberta S. Costa ${ }^{1}$, Daniel E. Caldevilla ${ }^{2}$, Paulo Rogério Gallo ${ }^{3}$, Brena Figueiredo Sena ${ }^{4}$, \\ Claudio Leone ${ }^{5}$
}

\begin{abstract}
Introduction: birth weight is an indicator for the evaluation of intrauterine growth (IUGR) as well as a mortality risk index. There are already a large number of studies on newborns (NB) with low birth weight (LBW), while studies on those with insufficient birth weight (IB) are rare, including those related to adequate or limited intrauterine growth. Objective: to estimate the incidence of underweight among infants born at term and the proportion of those who are small for their gestational age, within an urban clientele of the Brazilian public health system, Sistema Único de Saúde, SUS. Methods: observational study in a public maternity department of the hospital Regional de Cotia, in the metropolitan area of +São Paulo, which cares for of SUS patients. A universe of live births were evaluated in the last trimester of 2009, determining the proportion of IB infants and the adequacy of weight, based on gestational age and sex. Results: the incidence of insufficient birth weight was similar to that observed in the last two decades in Brazil, corresponding to $1 / 4$ of the total number of births. The proportion of small gestational age newborns (NB SGA) was small, affecting only $4.2 \%$ of the IB infants. In $90 \%$ of these infants no pathology was identified to explain IB. The proportion of cesarean births (47.1\%) among IB newborns as well as the difference in gestational age that they had in relation to the newborns of adequate weight, around four days, from the standpoint of IUGR does not justify the difference in mean weight between the two groups. Conclusion: the incidence of IB was high, however only a small proportion of these infants were small for gestational age. The data indicates the need for continued research on IB, including providing incentives for the continued improvement of public policies and programs regarding pre and peri-natal care.
\end{abstract}

Key words: birth weight, insufficient birth weight, newborn small for gestational age.

\section{INTRODUCTION}

Lifecourse events are vital processes inherent to life. However, to be born, grow, get sick and die, although they seem like the most natural occurences, do not occur unless there is at least one cause producing such events. According to this conception, birth weight can be understood as an indicator of gestational conditions, and more specifically the intrauterine growth, and, moreover, may be an important risk marker for infant morbidity and mortality ${ }^{1-4}$.

In the health field, due to its often higher risk, newborns of low birth weight (LBW) have too often been the object of research, however, more recently, studies have focused their attention on those with insufficient birth weight (IB), i.e. newborns (NB) whose birth weight is between 2500 and 3000 grams. Similarly to the LBW NB, the IB NB also seems to be a risk factor for many health issues, such as infectious diseases, especially diarrheal disease, acute respiratory infections, growth retardation and development. In addition, these infants have a higher mortality rate during the first year of life, when compared to newborns of normal weight ${ }^{5-13}$.

The importance of the NB IB also derives from its high incidence, observed in specific developed

1 Fisioterapeuta, Mestre em Ciências pela Faculdade de Saúde Pública da Universidade de São Paulo.

2 Médico Neonatologista, Coordenador do da Unidade Neonatal do Hospital Regional de Cotia.

3 Médico Pediatra, Professor Associado do Departamento de Saúde Materno-Infantil da Faculdade de Saúde Pública da Universidade de São Paulo.

4 Bachelor of Science (B.S) em Biologia e Pre-Medicina da University of Massachusetts, Amherst, MA, USA; Mestranda em Saude Publica (M.P.H.) em Ciencias Medico-Sociais e Saude Global da Columbia University, New York, NY, USA

5 Professor Titular do Departamento de Saúde Materno-Infantil da Faculdade de Saúde Pública da Universidade de São Paulo. Corresponding author: leone.claudio@gmail.com

Suggested citation: Costa RS, et al. Incidence and characteristics of insufficient birth weight newborns from a cohort of neonates in a public regional hospital of a metropolitan area; J. Hum Growth and Dev. 2013; 23(2): 238-243 Manuscript submitted Mar 22 2012, accepted for publication Feb 122013. 
countries. In Brazil, the incidence is 3 to 4 times higher than that of low birth weight, which corresponds to approximately $1 / 4$ of the total live births ${ }^{12-15}$.

For over 30 years, Puffer and Serrano ${ }^{15}$ stressed the importance of adequate weight at birth $(A B W),>3,000 \mathrm{~g}$, not only for the survival of the newborn, but also for the growth and healthy development of the child. In 1988, Puffer and Serrano ${ }^{3}$, published data on birth weights in different countries around the world. In India, between 1969 and $1972,45.8 \%$ of live births had IB. In 1973, Cuba's incidence of IB was $26.8 \%$ and it was $23.6 \%$ in Hungary, and $11.6 \%$ in Sweden. In 1977 the proportion of infants born underweight observed in Chile was $24.9 \%$ and $24.2 \%$ in Uruguay. In the United States, in 1983 , IB occurred in $16.1 \%$ of births.

The data highlights the importance of estimating the incidence of birth weight periodically and of assessing, based on the potential aggregate of consequences along the lifetime ${ }^{5}$, whether the intrauterine growth of these children was adequate. Since this study relates to children who are born with a weight well below the expected average weight for newborns at term, the distinction between a normal and a restricted intrauterine growth is especially important. For these reasons, the objective of this study was to estimate the incidence of underweight at birth in a user population of a maternity hospital member of the Unified Health System (SUS) of a major metropolitan area, and the proportion of these IB NB who were small for gestational age.

\section{METHODS}

This is an observational, descriptive study based on the universe of live births whide occurred in the last quarter of 2009, in the Maternity department of the Hospital Regional de Cotia, in the metropolitan region of Greater São Paulo. The anthropometric characteristics, pregnancy and delivery of newborns were obtained from the birth records at the Birth Center, Surgical and Obstetric Centers; medical charts and, when necessary, interviews were held with the mothers.

All 561 infants in the cohort were evaluated, including those in the study who were classified as of insufficient birth weight, ie, those with a birth weight of $2500 \mathrm{~g}-2999 \mathrm{~g}^{3}$, and those full term newborns with normal weight, ie between $3000 \mathrm{~g}$ and $3500 \mathrm{~g}$. Neonates classified as premature were excluded (under 37 weeks gestation) according to the Capurro score ${ }^{16}$ as well as the NB whose birth weight was greater than $3500 \mathrm{~g}$.

Data relating to the newborn was recorded by health workers, who are properly trained in birth registry. Weight was measured using electronic scales, with a maximum capacity of $15 \mathrm{~kg}$, with subdivisions of 10 grams, and their accuracy was periodically checked by a member of the research team. The length at birth was measured by two professionals of the healthcare team using a portable stadiometer, with a movable cursor and scale in centimeters and millimeters. The head circumference was measured with a measuring tape made out of inextensible fiberglass, positioned on the glabella and occipital protuberance, passing over the upper portion of the ear on both sides of the head.

All newborns with IB whose birth weight was below the 10th percentile of the Lubchenco reference intrauterine growth curve were classified as small for gestational age (SGA), in view of their sex and gestational age, the latter analysed by the Capurro method ${ }^{16}$.

The research project was approved by the IRB of the Faculty of Public Health, University of São Paulo, protocol $1748 / 2008$ and by the IRB of the Social Service of Civil Construction - SECONCI - SP, the entity responsible for administering the Hospital Regional de Cotia.

The municipality contains only one maternity hospital, which is integrated into the Hospital Regional de Cotia, whose aim is to cater not only to the population of its own municipality, but also provides services for the wider region's demand. It is, therefore, a maternity of reference for many services and social strata in the region, and primarily serves SUS users, along with lower socioeconomic strata of the population.

\section{RESULTS}

During the three months of data collection, the number of live births in the Hospital Regional de Cotia was of 561 children. Of the total births in the trimester, $49.8 \%$ were delivered vaginally and $50.2 \%$ by cesarean section.

Table 1 shows that of the total newborns, practically $1 / 4$ were NBs with IB while the proportion of infants born at term with normal weight, between 3000 and 3500 grams, was $42.2 \%$. Among the 144 IB newborns, only five (3.5\%) were diagnosed as being small for gestational age (SGA).

Table 1: Distribution of Newborns Based on Birth Weight Categories. Hospital Regional de Cotia, 2009

$\begin{array}{lcc}\text { Classification of Newborns } & \mathbf{n} & \% \\ \text { Adequate Birth Weight } & 237 & 42,2 \\ \text { IB* } & 144 & 25,7 \\ \text { Other } & 180 & 32,1 \\ \text { Total } & 561 & 100,0\end{array}$

*insufficient birth weight 
Four mothers of IB newborns, $2.8 \%$ of the total, refused to participate in the study. One child was excluded from the study because she was born at home, a fact that made it difficult to confirm the birth weight, and another 8 were also excluded because they were premature (gestational age of less than 37 weeks). As a result, the final sample used for this analysis finally consisted of 131 newborns with IB.

With regard to the average duration of gestational age among IB infants, this was 272.3 days (38 weeks and 6/7) with a standard deviation
(SD) of 7.2 days, while the average of normal birth weight was 275.7 days (39 weeks and 3/7) with a SD of 6.7 days, which corresponds to a difference in mean gestational age of 3.2 days.

As for the birth weight of the two groups, the means were of $2897.3 \mathrm{~g}(\mathrm{SD}=513.8)$ and 3255.9 $\mathrm{g}(\mathrm{SD}=460.7)$, respectively, for the IB NBs and normal weight NBs.

The proportion of cesarean births observed among IB newborns was $47.1 \%$ while among infants of birth weight between 3 and $3.5 \mathrm{~kg}$ it was slightly higher ( $51.2 \%$ of births).

Table 2: Anthropometric characteristics of newborns with insuficient birth weight and the median reference value according to the World Health Organization 2006, based on sex. Hospital Regional de Cotia, 2009

\begin{tabular}{|c|c|c|c|c|}
\hline $\begin{array}{c}\text { Characteristics } \\
\text { at Birth }\end{array}$ & $\begin{array}{c}\text { Newborns with } \\
\text { Insufficient Weight } \\
\text { (Cotia 2009) } \\
\text { Female } \\
\text { (n: } 67 ; 51,3 \%)\end{array}$ & $\begin{array}{c}\text { WHO } 200617 \\
\text { (Percentil 50) } \\
\text { Male } \\
\text { (n: 64; 48,7\%) }\end{array}$ & Female & Male \\
\hline Gestational Age & 39 weeks & 38 weeks and $5 / 7$ & Term & Term \\
\hline Weight & $2902,3 \mathrm{~g}$ & $2892,4 \mathrm{~g}$ & $3260 \mathrm{~g}$ & $3400 \mathrm{~g}$ \\
\hline Height & $46,5 \mathrm{~cm}$ & $47,2 \mathrm{~cm}$ & $49,1 \mathrm{~cm}$ & $49,9 \mathrm{~cm}$ \\
\hline Head Circumference & $33,0 \mathrm{~cm}$ & $33,0 \mathrm{~cm}$ & $33,9 \mathrm{~cm}$ & $34,5 \mathrm{~cm}$ \\
\hline
\end{tabular}

Among the 131 IB newborns within the sample, 6 were from multiple pregnancies, 4 were diagnosed with congenital toxoplasmosis and 3 had severe malformations. In the remaining 118 IB infants $(90.1 \%$ of the total) no conditions were identified that could be associated with IB.

\section{DISCUSSION}

The incidence of low birth weight found in this study is quite similar to the values tfound in previous research conducted in Brazil, accouting for around one quarter of total births, more precisely $25.7 \%$ of live births, which can be considered a high proportion.

Recent studies have shown that there is a very high proportion of cesarean births in Brazil ${ }^{18}$, including the metropolitan area of São Paulo, which theoretically, in a preliminary analysis, could be considered here as an important factor among those possibly related to the significant incidence rate of underweight infant births and, even worse, to the high frequency of premature births registered in Brazil ${ }^{19}$.

When evaluating the average rate within a country such as Brazil, one runs the risk of not being able to distinguish heterogeneous realities, which is why many studies conducted in different regions, need to be taken into consideration when one wants to deepen the analysis of statistical data from a particular site.

In this sense, a study of 277 pregnant women in 2003 at a maternity hospital in Teresina, Piauí, reported an incidence of IB of $19.5 \%{ }^{20}$. On the othert hand in Recife, Pernambuco, in 1991, in a sample of 5940 live births the incidence of IB was higher, reaching $31.0 \%{ }^{4}$. In Alagoas, during the period between 1985 and 1989 the observed incidence of IB was $20.3 \%{ }^{21}$.

Based on data from SINASC-1998, Costa et al. ${ }^{22}$, found an incidence of IB of $28.7 \%$, of a total of 10,164 live births in Feira de Santana, Bahia. Another study in João Pessoa, Paraíba, based on the data file of maternity hospitals, between 1989 and 1992 , evinced a proportion of $23.2 \%$ of IB ${ }^{23}$.

These results indicate that on average, in northeastern Brazil over the past two decades, as well as in Brazil as a whole, IB should correspond to about $1 / 4$ of neonates ${ }^{13-15}$, an average which is very close to the incidence rate observed in Cotia.

A study by Nobrega et al. ${ }^{24}$ at the Centro de Referência de Saúde da Mulher e de Nutrição, Alimentação e Desenvolvimento Infantil da Secretaria de Saúde do Estado de São Paulo, in São Paulo, showed a higher incidence of IB, corresponding to $28.2 \%$ of the cases studied. The likely explanation for this higher proportion is that it is due to the fact this is a referral center, hence it prioritizes assistance to high-risk pregnancies.

Lizo et al. ${ }^{25}$ reported that, in a private maternity hospital in São Paulo, the incidence of IB was $21 \%$. As noted, although this study was performed in a maternity hospital where most women attending are of high socioeconomic level, incidence of IB was not much different from that of the previously mentioned studies, performed in public hospitals serving users of the SUS system. 
Azenha et al. ${ }^{26}$ conducted a comparative study of all live births in 1978/79 and 1994 and found that there was a significant increase in the number of IBs in the municipality of Ribeirão Preto, in Sao Paulo; in $1978 / 79$ the proportion was of $22.4 \%$ rising to $28.7 \%$ in 1994 . This depicts an increase of 6.3 percentage points, an increase of almost $30 \%$ over 15 years.

During studies carried out at maternity hospitals in Campinas between 1975 and 1996, 24\% of total live births were IBs ${ }^{7}$. In the municipality of Santo André incidence was slightly higher at $26.0 \%{ }^{27}$. These values are higher than those found in a study conducted on a sample of 1533 children in Rio Claro, São Paulo, in 1991, which reported an incidence of IB at $18.6 \%^{28}$.

In 2001, a study conducted in Rio de Janeiro showed a $24.8 \%$ incidence of IB, which is also very close to that observed in this present study ${ }^{29}$.

In Colombia, in a study of 245 pregnant women the incidence of IB was $26.1 \%{ }^{30}$, very similar to the values obtained in Brazil ${ }^{12-14}$.

All of these studies seem to indicate that in recent years the incidence of IB has remained at values that correspond to about a quarter of the total live births. However, the analysis regarding this group of newborns has received very little attention in the literature, despite these childrens' having been identified in several national studies as having an increased risk of mortality and growth below the expected average, when compared to that which occurs with newborns with adequate weight ${ }^{11,30,32}$.

Although there are already studies that discuss SGA NB and intrauterine growth restriction, including its consequences in the short and long term, little study has been undertaken regarding the incidence of infants small for gestational age among IB infants, despite the relevance of this discussion, especially when considering the high proportion of cesarean births that occur in Brazil.

Considering the small proportion of SGA observed among IB newborns evaluated in Cotia, it can be assumed that many of these infants, although not classified as SGA by current criteria ${ }^{34}$, suffer some degree of intrauterine growth restriction, even if of low intensity, possibly during the last weeks of pregnancy, when weight gain is normally markedly higher. Strengthening this hypothesis is the fact that the majority of studies in Brazilian territory has a much higher proportion of NB than would be expected from the normal weight distribution as a function of birth weight for gestational age. Within this distribution, in standard deviation below the mean birth weight one would expect to find only $13 \%$ of newborns and not the $25 \%$ average observed. However, the difference is even greater, since in this proportion of $13 \%$ are also included LBW NB, which further reduces the proportion of infants with IB statistically expected in the normal population, and makes the incidence of IB observed in Cotia even more notworothy from in an epidemiological point of view.

The difference in the average weight of the IB group studied here and the median values of reference of the World Health Organization (WHO) for newborns at term (supposedly at 40 weeks gestational age) is approximately $500 \mathrm{~g}$.

A weight difference of this magnitude cannot be explained only by the lower gestational age of the insufficient birth weight newborns in Cotia, compared to the 40 weeks on average that the newborns of the WHO's reference values would theoretically have, estimated to be around nine days. This finding makes it unlikely that the incidence of IB, at least in most cases, can be attributed to the high proportion of cesarean deliveries, which allows for the assumption that problems occurring during pregnancy, not commonly detected in the current routine prenatal care, are also contributing so that these infants cannot reach their full growth potential already during intrauterine life. This hypothesis is also reinforced by the difference in average weight between IB infants, and those of normal weight in this study, with an average of $260 \mathrm{~g}$, which can hardly be attributed to the difference in gestational age between the groups; on average of 3.4 days.

The compromise also observed for length and head circumference at birth, not just the birth weight, corroborates this hypothesis, seeming to indicate further the existence of factors that affect fetal growth throughout pregnancy and not solely in its final stage.

These analyses are in line with results found in previous studies $33,35,36$, stressing that investiments are still needed in measures to improve adherence to and, above all, the quality of prenatal care, aiming not only at an increase in the number of visits, but also in the early adoption of such visits, and in evaluation mechanisms for the quality of care provided to pregnant women.

Finally, the persistence of high incidence of insufficient birth weight, as observed in Cotia, coupled with the relatively low proportion of small for gestational age infants among IB NBs with the socioeconomic changes that have occurred over the last 15 years, stress the urgent need for research relating to insufficient birth weight to continue to be undertaken in our midst; without reducing the attention given to improvements of policies and programs for pre-and perinatal care.

Nevertheless, future research should not be restricted only the monitoring of the incidence of IB over time, but should also increase knowledge concerning its determinants, and perform life course studies to evaluate the possible consequences that this birth condition may pose to individuals; and hence the consequences for society as a whole. 


\section{REFERENCES}

1. Donaldson PJ, Billy JOG. The impact of prenatal care on birth weight: evidence from an international data set. Med Care. 1984; 22: 177-88.

2. McIntire DD, Blomm SL, Casey BM, Leveno KJ. Birth weight in relation to morbidity and mortality among newborn infants. N Engl J Med. 1999; 340(16):1234-8.

3. Puffer RR, Serrano CN. Caracteristicas del peso al nascer. Washington (DC) Organización Panamericana de la Salud; p.89-95 (OPASPublicación Científica, n504), 1988.

4. Rocha JA. Baixo peso, peso insuficiente e peso adequado ao nascer, em 5.940 nascidos vivos na cidade do Recife. J Pediatr (Rio J). 1991; 67(9/10):297-304.

5. Barker DJP, editor. Mothers, babies and health in later life. 2nd ed. Edinburgh: Churchill Livingstone; 1998.

6. Gomes JO, Santo AH. Infant mortality in a midwestern municipality of the State of São Paulo, Brazil, 1990 to 1992. Rev. Saúde Pública. 1997; 31 (4): 330-41.

7. Mariotoni GGB e Barros Filho AA. Peso ao nascer e mortalidade hospitalar entre nascidos vivos, 1975-1996 Rev. Saúde Pública. 2000; 34 (1): 71-76.

8. Moraes IB. Fatores de risco para peso insuficiente ao nascer [dissertação de mestrado]. Campinas (SP): Unicamp; 2001.

9. Santa Helena ET, Souza CA, Silva CA. Fatores de risco para mortalidade neonatal em Blumenau, Santa Catarina: Linkage entre bancos de dados. Rev Bras Saúde Mater. Infant. 2005; 5 (2): 209-217.

10. Victora CG, Barros FC, Martines JC, Boria JU, Vaughan JP. Estudo longitudinal das crianças nascidas em 1982, em Pelotas, RS, Brasil: metodologia e resultados preliminares. Rev. Saúde Públ. 1985; 19: 56-68.

11. Yamamoto RM, Schoeps DO, Abreu LC e Leone C. Peso insuficiente ao nascer e crescimento alcançado na idade pré-escolar, por crianças atendidas em creches filantrópicas do município de Santo André, São Paulo, Brasil. Rev. Bras. Saude Mater. Infant. 2009; 9(4): 477-485.

12. Almeida LAA, Barbieri MA, Gomes UA, Reis PM, Chiarati TM, Vasconcelos V. Peso ao nascer, classe social e mortalidade infantil em Ribeirão Preto, São Paulo. Cad Saúde Pública. 1992; 8(2): 190-8.

13. Almeida MF, Novaes HMD, Alencar GP, Rodrigues LC. Mortalidade perinatal no município de São Paulo: influencia de peso ao nascer e de fatores sócio-demográficos e assistências. Rev. Bras Epid. 2002; 5(1): 93-107.

14. Gomes JO, Santo AH. Infant mortality in a midwestern municipality of the State of São Paulo, Brazil, 1990 to 1992. Rev. Saúde Públ. 1997; 31 (4): 330-41.
15. Puffer RR, Serrano CV. El peso al nascer, la edad materna y el orden de nacimiento: tres importantes factores determinantes de la mortalidad infantil. Publicación científica 294. Washington: Organización Panamericana de la Salud, 1975.

16. Capurro H, Konichezky S, Fonseca D, CaldeyroBarcia R. A simplified method for diagnosis of gestational age in the newborn infant. J Pediatr. 1978; 93: 120-2.

17. Grummer-Strawn LM, Reinold C, Krebs NF, Centers for Disease Control and Prevention (CDC). Use of World Health Organization and CDC growth charts for children aged 0-59 months in the United States. MMWR Recomm Rep. 2010.

18. Potter JE, Berquo E, Perpetuo IH, Leal OF, Hopkins K, Souza MR, et al. Unwanted caesarean sections among public and private patients in Brazil: prospective study. BMJ. 2001; 323:1155-8.

19. Barros FC, Vaughan JP, Victora CG, Huttly SR. Epidemic of caesarean sections in Brazil. Lancet 1991; 338: 167-69.

20. Lima GSP e Sampaio HAC. Influencia dos fatores obstétricos, socioeconômicos e nutricionais da gestante sobre o peso do recém-nascido: estudo realizado em uma maternidade em Teresina, Piauí. Rev.Bras. Saúde Matern. Infant. 2000; 44(3): 253-261.

21. Florencio, TMT. Comportamento do peso ao nascer em seis maternidades do estado de Alagoas 1985-1989. Recife; s.n; 1992. 73 p.

22. Costa MC, Santos CAT, Sobrinho CL, Freitas JO, Ferreira KASL. Indicadores materno-infantis na adolescência e juventude: Sociodemográficos, pré-natal, parto e nascidos vivos. J Pediatr (Rio J). $2001 ; 77$ (3): 235-42.

23. Santana, PR; Rivera, MAA; Nakamura, P; Nogueira, M; Lima, RT; Nakamura, E; Muniz, KC; Aragäo, AJ. Evolução do peso ao nascer no munícipio de Joäo Pessoa/PB - 1989/1992. CCS 1994; 13(1): 39-46, jan.-mar.

24. Nóbrega FJ; Vítolo MR; Queiroz SS; Magrini JE. Crianças desnutridas internadas: relaçäo com variáveis maternas. Rev. Paul. Pediatr 1994; 12(3): 286-90.

25. Lizo CLP, Azevedo-Lizo Z, Aronson E, Segre CAM. Relação entre ganho de peso materno e peso do recém-nascido. J Pediatr (Rio J). 1998; 74(2): 114-8.

26. Azenha VM, Mattar MA, Cardoso VC, Barbieri MA, Ciampo LAD, Bettiol H. Peso insuficiente ao nascer: estudo de fatores associados em duas coortes de recém-nascidos em Ribeirão Preto, São Paulo. Rev. Paul. Pediatr. 2008; 26(1):21-35.

27. Bellingham-Young DA, Adamson-Macedo EN. The impact of birthweight on adult minor illness: a study on a sub-clinical population. J. Hum Growth and Dev 2013; 23(1):1-10. 
28. Fisberg, M; Makssoudian, A; Castellotti, DS; Jarmy, ZIK. A influência do peso de nascimento na modificaçäo do estado nutricional. Rev. Paul. Pediatr 1992; 10(36): 3-6,

29. Barbas DS, Costa AJL, Luiz RR, Kale PL. Determinantes de peso insuficiente e do baixo peso na cidade do Rio de Janeiro, Brasil, 2001. Epidemiol. Serv. Saúde, Brasília 2009, 18 (2): 161-170.

30. Benjumea, M V. Exactitud diagnóstica de cinco referencias gestacionales para predecir el peso insuficiente al nacer. Biomédica 2007; 27: 42-55.

31. Antonio MARGM, Zanolli ML, Carniel EF, Morcillo AM. Fatores associados ao peso insuficiente ao nascimento. Rev. Assoc. Med. Bras. 2009; 55(2): 153-7.

32. Motta MEFA, Silva GAP, Araújo OC, Lira PI, Lima MC. O peso ao nascer influencia o estado nutricional ao final do primeiro ano de vida? J Pediatr (Rio J). 2005; 81(5): 377-82.

33. Nóbrega FJ, Vitolo J, Brasil MR, Dias AL, Lopez FA. Condição nutricional de mães e filhos: relação com peso de nascimento, variáveis maternas e socioeconômicas. J Pediatr (Rio J). $1991 ; 67$ (9/10): 288-96.

34. Altman DG, Hytten FE. Intrauterine growth retardation: Let's be clear about it. $\mathrm{Br}$ J Obstet Gynecol 1989; 96: 1127-8.

35. Leone, C, Mascaretti, LAS, Primo, E, Yamamoto, TS e Freschi, SA. Peso de nascimento e características médico-sociais. J Pediatr (Rio J). 1992; 11/12: 376-379.

36. Amit Mukerji A; Belik J. Impact of birth-weight on adult minor illness. J. Hum Growth and Dev 2013; 23(1): 7-10 
